\title{
Lexicons in the Gayo Isolectal Variations: A Dialectologic Study
}

\author{
Dardanila $^{1 *}$ and Haris Sutan Lubis ${ }^{1}$ \\ ${ }^{1}$ Faculty of Cultural Sciences, University of Sumatera Utara, Medan, Indonesia \\ *Corresponding Author: Dardanila, Faculty of Cultural Sciences, University of Sumatera Utara, \\ Medan, Indonesia
}

\begin{abstract}
This study describes the lexicons in the Gayo dialectal variations using the theory of structural dialectometry. It was carried out in Bebesan district and held at 10 observation points which were used as the research areas and invloved one informant at each point. Data collection was using speech method with various techniques, such as, stimulating, face-to-face, noting, and recording. Data analysis is based on the articulatory coherent method by determining the specifying instrument of speech organ referrent, the split technique of determinant element, and the comparative and interconnective technique for comparativeness and contrastiveness. From the results, it is concluded that from 200 vocabularies, there are only 100 lexical variations. In case of variations from observation points, there are three categories, for example, the category of no differences (0\%-20\%), of speech differences (21-30\%), and of subdialectal differences (31-50\%).
\end{abstract}

Keywords: Variation, Isolect, Gayo language, lexical, variants

Abbreviations: $O P=$ observation point

\section{INTRODUCTION}

Language variation is used in a certain area so different linguistic elements might be formed, such as, in grammar and meaning. Chaer (2006: 62) said that variations of language can be based on the speaker and its usage. ${ }^{[1]}$ The study of language variations is called dialect. Dialect is a linguistic system used by a society to distinguish it from other neighboring societies who use different systems although they are closely related. Mahsum (1995: 11) said that dialectology is a linguistic branch that examines the differences of isolects by treating the differences as a whole. ${ }^{[2]}$

The term isolect is proposed by Petyt Adelaar, which is used to refer to the form of language regardless of its status as a language or as a dialect. ${ }^{[3]}$ The term isolect is a neutral term that can be used to refer to a language, dialect or subdialect. The geographical isolation of Gayo language isolatect can be described. Gayo is one of the regional languages of Aceh Province whose speakers are called Gayo people. Gayo language is used by Gayo community to communicate in everyday life. Gayo language is widespread some parts of Southeast Aceh. ${ }^{[4],[5]}$

\section{MATERials AND Methods}

\subsection{Determining the Observation Areas}

The isolectal variations are obtained from informants who meet certain requirements and they come from ten observation points (OPs) in districts of Bebesen, Takengon regency, Central Aceh.

\subsection{Method and Technique of Data Collection}

Method and technique of data collection in this study is speech method in which there are communication between researchers and their informants. The speech method has basic technique, namely, stimulating technique with one reason that the expected conversation may arise if the researchers give stimulation to informant(s) and this condition is used to seek language phenomenon that the researchers hope to find (see [2]). It is followed then by face-to-face technique. Researchers visited directly to the areas of observation and conducted conversations guided by a list of questions that have been provided. This technique is also supported by noting and recording. 


\subsection{Methods and Techniques of Data Analysis}

Data analysis uses the method of matching, that is, a method of articulatory coherence with a speech organ referencing tool. The basic technique used is the the technique of sorting out certain elements, that is, the articulator determinants. This technique can sort out various isolectal sounds in the observation areas. This technique is followed by the appeal technique of equation and differentiation. This technique becomes the determinant to find similarities and differences in the various isolects of Gayo data lexicon.

\subsection{Theoratical Reviews}

The word dialect comes from the Greek dialectos 'variations'. In subsequent developments the word dialectos is used to express the language system used by a society at different locations or geographical locations. Kridalaksana (1993: 42) argued that language variations refer to speech variation of speakers in communication due to geographical differences. ${ }^{[6]}$ This may result in the distinction of language variations. If these variations arise due to the social status of language users then the dialect is discussed under sociolinguistics; however, if the language elements used by different speakers are caused by different places, then the assessment should relate to dialect geography.

\section{RESULTS AND DiSCUSSION}

There are 50 data which is mapped for analysis and taken from some number of the data collection. The overall data is 100 vocabularies. The mapping results are then calculated to see the different isolatects at each observation point. The benefit of calculating lexicons between points of observation is to determine the percentage of linguistic distance among the points. A different lexicon might happen if the lexemes used to realize a similar meaning do not come from a pre-language etymon. All differences in lexicon always appear in the form of variations. Of all glosses of data, the variants of lexicon are selected.

1. Gloss alir (me) 'to flow'

About this gloss there are two different variants: [jalir] and [manut]. The first is found at OPs 1, 2, 3, 4 , and 5 and the second at $6,7,8,9$, and 10 .

2. Gloss angin 'wind'

There is a single variant of this gloss, that is, [kuyu] which is available at OPs $1,2,3,4,5,6,7,8,9$, and 10.

\section{Gloss apa 'what'}

There are two different variants from the gloss apa: [hana] and [sana]. The first is observed at OPs 1 , $2,3,9$, and 10 and the second at 4, 5, 6, 7, and 8 .

4. Gloss asap 'smoke'

This gloss has only one variant, namely, [asap] which is discovered at OPs 1, 2, 3, 4, 5, 6, 7, 8, 9, and 10.

5. Gloss bakar 'to burn'

There are two different variants of this gloss: [telong] and [seut]. The first is noticed at OPs 1, 2, 5, 6, and 7 and the second at 3, 4, 8, 9, and 10 .

\section{Gloss basah 'wet'}

Two variants are founf for this gloss: [basah] and [remo]. The first is available at OPs 1, 2, 3, 4, 5, 6, and 7 and the second at 8,9 , and 10 .

\section{Gloss benar 'true'}

This gloss also has two variants: [sunguh] and [betul]. The first variant is supplied from OPs 1, 2, 3, 4, and 5 and the second from $6,7,8,9$, and 10 .

8. Gloss bengkak'swollen'

There are two different variants from this gloss: [kemung] and [tebok]. The variant [kemung] is found at OPs 1, 4, 5, 6, and 10 and the second variant at OPs 2, 3, 7, 8, and 9. 
9. Gloss buah 'fruit'

This gloss has one variant, that is, [uah] which is noticed at OPs 1, 2, 3, 4, 5, 6, 7, 8, 9, and 10.

10. Gloss cium 'to kiss'

This gloss has two variants: [cemoh] and [cum]. The first variant is contributed from OPs 1, 3, 5, 6, 8, and 10 and the second from OPs 2, 4, 7, and 9.

11. Gloss cuci 'to clean'

There are two different variants of this gloss: [sesah] and [ningo] and they are doscovered at OPs 1,2, 3,4 , and 5 for the first variant and at $6,7,8,9$, and 10 for the second one.

12. Gloss datang 'to come'

There is only one variant of this gloss, namely, [geh] and it is detected at OPs $1,2,3,4,5,6,7,8,9$, and 10 .

13. Gloss daun 'leaf'

The gloss daun has one variant, that is, [ulung] which is seen at OPs 1, 2, 3, 4, 5, 6, 7, 8, 9, and 10.

14. Gloss garam 'salt'

There are two different variants of this gloss: [poa] and [sira]. The first is available at OPs 1, 2, 3, 4, 5, 6 , and 7 and the second at OPs 8, 9, and 10 .

15. Gloss hisap 'to suct'

This gloss has two variants, namely, [siluk] and [isep] which are perceived at OPs 1, 2, 6, 7, and 10 for the first variant and at 3, 4, 5, 8, and 9 for the second one.

16. Gloss lihat 'to see'

There are two different variants of this gloss: [engon] and [erah]. The first variant is taken from OPs $1,2,3,4$, and 5 and the second from $6,7,8,9$, and 10 .

\section{Gloss ludah 'spit'}

There is only one variant of this gloss, namely, [ari] which is found at OPs $1,2,3,4,5,6,7,8$, 9, and 10.

18. Gloss mulut 'mouth'

This gloss has one vriant, namely, [awah] which is available at OPs 1, 2, 3, 4, 5, 6, 7, 8, 9, and 10.

19. Gloss panjang 'long'

There are two different variants of this gloss, namely, [naru] and [ganyong] [naru]. The first variant is detected at OPs 1, 2, 8, 9, and 10 and second one at OPs 3, 4, 5, 6, and 7.

20. Gloss peras 'to squeeze

Two variants of this gloss are found, such as, [pecik] and [lie] which are noticed at OPs 1, 2, 5, 6, and 7 for the first variant and at 3, 4, 8, 9, and 10 for the second one.

21. Gloss pondok 'cottage'

There are two variants of this gloss, for example, [jamur] and [seladang]. The first variant is remarked at OPs 1, 7, 8, 9, and 10 and the second one at OPs 2, 3, 4, 5, and 6 .

22. Gloss rambut 'hair'

There are three different variants of gloss: [uwok], [uk] and [huk] which are respectively found at OPs $1,2,3,4,5$, and 6 , at 7 , and 8 , and at 9 , and 10 .

23. Gloss tarik 'pull'

This gloss has two variants: [tegu] and [eyat]. The first variant is observed at OPs 1, 4, 6, 8, and 9 and the second one at OPs 2, 3, 5, 7, and 10.

\section{Gloss sendok 'spoon'}

This gloss has only one variant, namely, [cemca] found at OPs 1, 2, 3, 4, 5, 6, 7, 8, 9, and 10. 
25. Gloss nyamuk 'mosquito'

There are two different variants of this gloss: [namuk] and [lemis] which are respectively observed at OPs $1,2,3,9$, and 10 and at 4, 5, 6, 7, and 8 .

26. Gloss ambil 'take'

This gloss has two variants, for example, [uweten] and [eten]. The first variant appears at OPs 1, 2, 3, 9 , and 10 and the second one at $4,5,6,7$, and 8 .

27. Gloss air 'water'

There are five different variants of this gloss: [weh], [wes], [waih], [aih] and [wih]. These variants are respectively found at OPs 2,7 , and 8 , at 6 , at 3 , and 5 , at 1 , and finally at 4,9 , and 10 .

28. Gloss tangan 'hand'

There are two different variants here: [pumu] and [kumu]. The two variants are in sequence observed at OPs 1, 2, 9, and10, and at 3, 4, 5, 6, 7, and 8 .

29. Gloss tempat sirih 'betel container'

This gloss has two variants: [bebakon] and [kampil] which are consecutively available at OPs 6, 7, 8, and 9 , and at $1,2,3,4,5$, and 10 .

30. Gloss rumah 'home'

There are two variants of this gloss: [umah] and [jamur]. The first is observed at OPs 4, 5, 6, and 10, and the second $1,2,3,7,8$, and 9 .

\section{Gloss jendela 'window'}

Two variants are found for this gloss, such as, [tingkep] and [jendela]. Berber [tingkep] was found on TP: 6,7,9, and berries [window] were found on TP: 1,2,3,4,5,8,10.

\section{Gloss halaman 'yard'}

This gloss has two variants: [elem-elem] and [halaman] which are respectively found at OPs. 5, 7, 8, and 10 , and at $1,2,3,4,6$, and 9 .

\section{Gloss abu dapur 'kitchen ash'}

Three different variants are observed from this gloss: [au], [wau] and [dul]. These variants are consecutively available at OPs 6,7, and 8, at 3,4, and 5 and at 1,2, 9, and 10.

\section{Gloss telinga 'ears'}

There are three different variants of this gloss, such as, [kemereng], [cuping] and [kacuping]. Those variants are respectively found at 3, 4, 5, 8, 9, and 10, at 6 . And 7 and at 1 , and 2 .

35. Gloss jantung 'heart'

There are two different variants of this gloss, for instance, [sosop] and [heart] which are noticed at OPs $1,2,6,7,8,9$, and 10 for the first, and at 3,4 , and 5 for the second.

36. Gloss tubuh 'body'

There are four different variants of this gloss: [jasad], [rembege], [beden] and [tubuh] which are in sequence found at OPs 3, 5, and 6, at 7, 8, and 9, at 1,2,3, and 4 and at 5, 6, 7, 8, and 10 .

37. Gloss nangka 'jackfruit'

This gloss has two variants: [tenen] and [nangka]. The first variant is detected at OPs 6, 7, 8, 9, and 10 , and the second one at $1,2,3,4$, and 5 .

38. Gloss cacing 'worms'

The gloss cacing has three variants: [cacing], [pacing], and [ketol]. The three variants are discovered respectively at OPs $3,4,5$, and 6 , at $1,2,6$, and 9 , and at 7,8 , and 10 . 
39. Gloss desak 'to urge'

There are two different variants of this gloss, namely, [asak] and [jejel]. The first variants is seen at OPs 1 , and 2, and the second one at 3, 4, 5, 6, 7, 8, 9, and 10 .

40. Gloss masuk 'to enter'

The gloss masuk has three different variants, for instance, [ayo], [mayo] and [cop]. The first variants is noticed at OPs 1, 2, 3, 4, 7, and 8, the second one at 5, 6, and 9, and the last one at 5, 6, and 10 .

\section{Gloss cepat 'fast'}

This gloss has six variants, such as, [bidik], [tir], [bacar], [serapah], [pantas] and [pejem] which are respectively found at $1,2,7,8$, and 9 , at 3, 4, 6, 7, and 8, at 3, 4, 6, and10, at 1, and 2, at 1,2, and 5, and at 5 , and 6 .

\section{Gloss genggam 'to hold'}

Two types of variants, for instance, [kemul] and [kecal] are seen from the gloss genggam and they appear in sequence at OPs 1,2,3,4, and 6, and at 5, 7, 8, 9, and 10.

\section{Gloss potong 'to cut'}

The gloss potong has three variants, such as, [gertak], [gertul] and [puntung] which are found respectively at OPs 3, 4, and 5, at 1,2, and 9, and at 6, 7,8, and 10 .

44. Gloss bicara 'to talk

There are two different variants of this gloss, for instance, [cerak] and [becerak] which are in sequence found at OPs $1,2,3,4,5$, and 9 , and at 6, 7, 8, and 10 .

45. Gloss tarik 'to pull'

Three different variants, namely, [tegu], [sintak] and [eyat] of the gloss tarik are found and they are discovered at OPs $3,4,5$, and 9 , at 6, 7, and 8 , and at $1,2,3,4,6$, and 10 .

\section{Gloss angkat 'to lift'}

This gloss has three variants, for instance, [angkut], [tunyak], and [tatang] which are noticed respectively at OPs 6 , at 1,2 , and 9, and at $3,4,5,7,8$, and 10 .

\section{Gloss meninggal 'to die'}

This gloss is rich of variants, for instance,[tuskesah], [mate], [los], [bensa], and [jengkong], which are conscutively discovered at OPs 5 , at 1,3,4,7,8, and 10, at 6, 7, and 8, at 2, 3, 4, 5, and 9, and at 1 , and 6.

\section{Gloss henti 'to stop'}

Three different variants of the gloss henti are [teduh], [reden], and [dong]; they are respectively noticed at OPs $1,2,7,8$, and 10 , at 1,2 , and 6 , and at $3,4,5,6$, and 9 .

49. Gloss pukul 'to hit'

Four different variants of the gloss pukul are noted from fields, such as, [derre], [gues], [tetok], and [pepok]. Those variants are respectively discovered at the following OPs, such as, at 3, 4, and 5, at 3, $4,5,8$, and 9 , at 6,7 , and 8 , and at 1,2 , and 10 .

\section{Gloss taruh 'to put'}

The gloss taruh is rich of variants and there are six noted variants, for example, [ben], [beben], [buh], [bubuh], [bun], and [bubun] which are consecutively found at different OPs, such as, at OPs 3, 4, and 5 , at $3,4,5$, and 10 , at 6,7 , and 8 , at 6,7 , and 8 , at 1 , and 2 , and at 1,2 , and 9 .

\section{CONClusions}

It is concluded that language variants in Gayo language in Bebesen district remain available and there are 100 isolect variations from 200 lexicons which were collected in the field. About variations among the observaton points, there are three categories: i) the category of no difference $(0-20 \%)$, ii) of any differences of speech (21-30\%), and iii) of any differences in the sub-dialect (31-50\%). 


\section{ACKNOWLEDGEMENT}

This research was financially supported by a grant of University of Sumatera Utara (USU) provided to the first author. The authors pay gratitude to all informants for their significant help and comments on field-data. The authors also thank to the anonymous reviewers and to Muhammad Ali Pawiro who assisted in the proofreading and manuscript editing.

\section{REFERENCES}

[1] Chaer, Abdul. 2006. Tata Bahasa Praktis Bahasa Indonesia. Jakarta: Rineka.

[2] Mahsum. 1995. Dialektologi Diakronis: Sebuah Pengantar. Yogyakarta: Gadjah Mada University Press.

[3] Petyt, K.M. 1980. The Study of Dialect: An Introduction to Dialectology. London: Andre Deutsch Limited.

[4] A. K, Baihaqi dan Abdul Gani Asyik dkk. 1981. Bahasa Gayo. Jakarta: Pusat Pembinaan dan Pengembangan Bahasa Depdikbud.

[5] Akbar, Osra. M dan Wawad Abdullah dkk. 1985. Pemetaan Bahasa Aceh Gayo dan Alas. Jakarta: Pusat Pembinaan dan Pengembangan Bahasa Depdikbud.

[6] Kridalaksana, Harimurti. 1993. Kamus Linguistik. Jakarta: Gramedia.

Citation: Dardanilal \& Haris Sutan Lubis "Lexicons in the Gayo Isolectal Variations: A Dialectologic Study" International Journal of Humanities Social Sciences and Education (IJHSSE), vol 4, no. 11, 2017, pp. 72-77. doi:http://dx.doi.org/10.20431/2349-0381.0411008.

Copyright: ( $) 2017$ Authors. This is an open-access article distributed under the terms of the Creative Commons Attribution License, which permits unrestricted use, distribution, and reproduction in any medium, provided the original author and source are credited. 